\title{
Current Status and Possible Solutions to the Financing Difficulties of Small- and Medium-sized Enterprises in China
}

\author{
R. LIU, J.H. SUI \& L.T. JIANG \\ College of Economic Management, Dalian University, Dalian 116622, China
}

R. LIU

School of Business Management, Northeastern University, Shenyang 110004, China

\begin{abstract}
The reform and opening-up policy in China has resulted in a good environment for the development of small- and medium-sized enterprises (SMEs), especially the burgeoning SMEs in the private sector. SMEs have been playing an important role in China's economic reform and development and, to some extent, have become a growth engine in the Chinese economy. However, SMEs are still facing many financial difficulties. Thus, in the present paper, the current financial status and financial environments of SMEs in China are studied and compared with several of the western countries, and a capital-cycle-based capital utilization pattern is proposed, that is, to increase government support to control the capital investment of the enterprise, take advantage of the core competencies to ensure the full capital utilization of the enterprise, screen life cycle of the enterprise to reasonably withdraw the capital. Meanwhile, some related cases are illustrated. In the end, some concluding remarks are drawn and some suggestions are proposed.
\end{abstract}

KEYWORD: Financing difficulties; Small- and medium enterprises; Capital investment

\section{INTRODUCTION}

China's economy has grown phenomenally since it was reformed and opened up more than two decades ago. The last 20 years have seen the creation of a modern, market-based economy whose growth has continuously outpaced the world's major economies. While China is currently the world's second largest economy, the World Bank has said it may overtake the United States as the world's largest by about 2025 as shown in Figure 1. Since the start of its market reforms in 1978, China has achieved a gross domestic product average annual growth rate of more than $9 \%$ before 2008. After 2008, the average annual growth rate of the gross domestic product decreases slightly due to the effect of world economic crisis in 2008, but on the whole, the China's economy was stable and improved compared with other main economic body, as shown in Figure 2, in which data sourced from World Bank.

According to report on the work of the government by Premier Keqiang Li in 2014, the gross domestic product (GDP) reached 56.9 trillion yuan, an increase of $7.7 \%$ over the previous year. The rise in the consumer price index (CPI) was kept at $2.6 \%$. The registered urban unemployment rate was kept at $4.1 \%$ and 13.1 million urban jobs were created, an all-time high. Total imports and exports exceeded US\$4 trillion, reaching a new high.
Personal income continued to rise, and economic performance continued to improve. The per capita disposable income of urban residents rose by $7 \%$ in real terms, and the per capita net income of rural residents rose by $9.3 \%$ in real terms. The number of rural people living in poverty was reduced by 16.5 million and the urban-rural income gap continued to narrow. The profits of industrial enterprises with annual revenue of 20 million yuan or more from their main business operations rose by $12.2 \%$. Government revenue increases by $10.1 \%$. The pilot project to replace business tax with value-added tax (VAT) was expanded, and 348 administrative fees were either canceled or exempted, thus reducing the burden on businesses by more than 150 billion yuan. All this further improved the market environment and invigorated businesses. The number of newly registered businesses increases by $27.6 \%$ nationwide. Private investment increased to $63 \%$ of the country's total investment. Meanwhile, the main targets for China's economic and social development in 2014 are set as follows: Increase GDP by about $7.5 \%$, keep the rise in the CPI at around $3.5 \%$, create ten million more urban jobs, ensure that the registered urban unemployment rate does not rise above $4.6 \%$, achieve basic balance in international payments, and increase personal incomes in step with economic development 


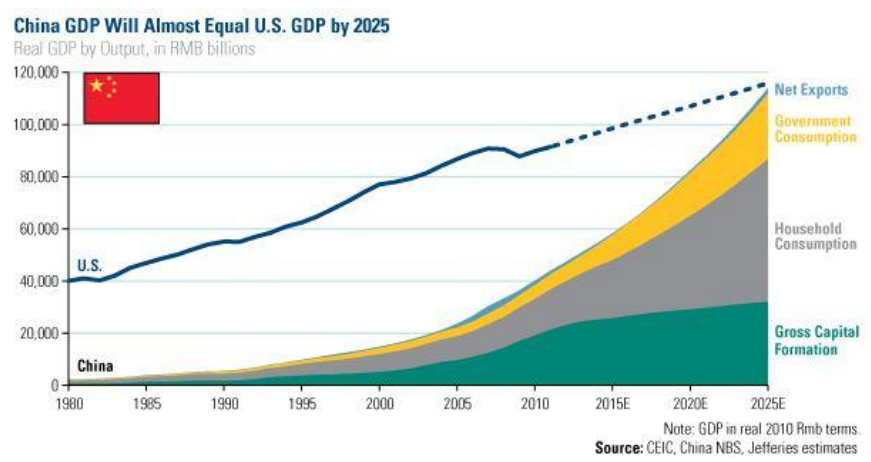

Figure 1. Trend between China GDP and U.S. GDP by 2015.

At the same time, hundreds of thousands of domestic firms have sprung up, from Small- and Medium-sized Enterprises (SMEs) to large corporations, and China has become one of the most competitive business environments in the world. SMEs support the steady, sustainable economic growth and assist the development of China's market economy. According to the China Business Handbook issued by U.S. Commercial Service in 2013, U.S. small and mid-sized enterprises in particular are major beneficiaries of China's economic growth and increasingly consumeroriented society. With a rapidly rising middle class and intense urbanization, SMEs are meeting China's demand for American goods. SMEs represented 92 percent of all U.S. exporters to China, and 78 percent of the total value of goods exported to China in 2010. In 2012, SMEs accounted for 65 percent of the country's all invention patents, 75 percent of corporate innovations and 80 percent of new product developments. SMEs comprised 99 percent of all firms, account for 60 percent of GDP and fiscal revenues and employed nearly 80 percent of the country's population. SMEs have become a major force in pushing forward China's science and technology innovation. Hence, Chinese SMEs play an important role in China's economic development, due to their contribution to GDP and the employment they create, as well as their vigorous creative ability.

In addition, it is stipulated that 'We should enhance the core competitiveness of large and medium-sized enterprises and support development of small and micro businesses, especially small and micro science and technology companies' in the report, 'Firmly march on the path of socialism with Chinese characteristics and strive to complete the building of a moderately prosperous society in all respects', to the eighteenth National Congress of the Communist Party of China. It follows that it is of great importance to further develop small and micro enterprises. However, the capital chain crisis of SMEs in Wenzhou, Zhejiang province, in recent years has led to all levels of government concern. The Wenzhou city government introduced a number of solutions to SME debt crisis of the measures, including banking institutions are not required divestiture, the local government transferred 25 working groups stationed in the city's banks to prevent loans bank divestiture pressure strand breaks leading to finance for SMEs. Wenzhou Banking Bureau has asked local banks to reduce lending rates cannot exceed $30 \%$ of the maximum floating; such as corporate financial crises involving banks loans between banks to "retreat into the same", not a single divestiture. The funding strand breaks of SMEs in Wenzhou indicate that the main problem restricting the development of small and micro enterprises mainly concentrated exposure to its financing problems and related issues. Therefore, how to crack the financing problem of small and medium enterprises in China has been pressing the pendulum in front of us.

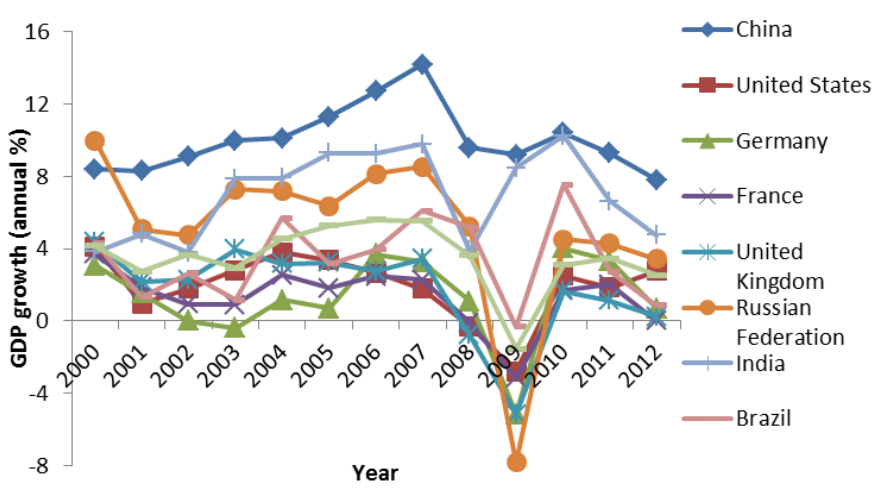

Figure 2. Comparisons of annual GDP growth between China and other main countries

As we all know, the funding cycle of revolving can be abstracted as raising funds for the use and allocation of funds for small businesses, production, marketing, and other day-to-day activities expand is associated with this funding cycle turnover and expanded. Thus, we can analyze the bottleneck problems in the development of small and micro enterprises from a financing point. From raising funds, the use of funds and funds exit to explore some of the issues that need to pay attention to the small and micro enterprises in the process of financing. The financing difficulties for small and medium-sized enterprises have received attention from both the public and the government, which has stressed that the problem should be a key concern for policy makers. In spite of this, these difficulties have not been solved; in fact, to some extent, they have intensified. The current financing environment of SMEs, the reasons for these problems are analyzed in this paper, and the countermeasures to financing difficulties of SMEs are also offered, from the view of the government as well as from the banks

\section{CURRENT FINANCING ENVIRONMENT OF SMES}

It is now well-known that small businesses are not 
'scaled-down versions' of large businesses. The process by which a large business has achieved its current size is of course one of evolution rather than scaling, and this process of evolution will involve major changes in management structure and functioning, in particular in the methods by which the business is financed. The simplest and most readily available representation of a firm's finances is to be found in the firm's accounts data. Hughes (1997) provides an overview of recent trends in the financing of smaller businesses in the U.K, beginning with an analysis of a large UK sample of small business accounts. It refers in particular to the findings of a major recent programme of work in this area funded by the Economic and Social Research Council, in which the author participated. This programme included the first national survey to address these issues since the Bolton Report of 1971, as well as a range of projects covering the finance of ethnic businesses and hi-tech firms as well as the market for informal venture capital. On the basis of this work and of the results of more recent follow up surveyors it is concluded that the evidence for general equity or debt gaps in the U.K. is weak. If anything SME funding was too easy in the boom of the late 1980s. It is argued that consideration could be given to the promotion through seedcorn funding of SME co-operative or mutual guarantee schemes to reduce information asymmetry in U.K. credit markets. Levratto (1996) presents the main financial characteristics of French SMEs: the low level of equities, the heaviness of short term debts and the over use of payment delays. He also shows how French and European authorities reacted in order to improve the financial situation of SME's and to reduce their liquidity constraint, changing tax policy and promoting the creation of new means of financing. Mambula (2002) investigates the factors that influence the growth, performance, and development of SMEs in Nigeria and what implications these factors have for policy on the basis of 32 small business entrepreneurs interviewed across the country. Eyiah and Cook (2003) presents a case study of financing small and medium-scale contractors in developing countries combined with Ghana. Fagan and Zhao (2009) discusses the financing of the SMEs in China, the related problems and the possible solutions.

Over the past two decades, Chinese small and medium-sized enterprises (SMEs) have gone through roughly three development phases (Chen, 2006), along with the development of China's reform and opening-up. The first phase was from 1978 to 1992, characterized by the expansion of SMEs in number and scale. This resulted from the government's encouragement of and support for the development of township, collective and self-employed enterprises. The rapid expansion of these enterprises has made great contribution to economic development and improvement of the people's living standards. The second phase was from 1992 to 2002. During this period, the emphasis was reform of stateowned SMEs and the development of non-public sectors. The government adopted various measures, such as restructuring, merger and acquisition, joint partnership, leasing, contracting and sell-off, to speed up reforms of state-owned SMEs and to gradually reduce the state's ownership in SMEs. At the same time private-owned SMEs enjoyed rapid development along with the establishment of the socialist market economy. The phase was an important historical period for the development of Chinese SMEs. The third phase began with 2002. In June 2002, China promulgated the small and medium-sized enterprises promotion law, which symbolized that the development of SMEs has ushered in a new era. On the whole, Chinese SMEs have gained a fast growth ever since the reform and opening-up, measured in terms of size, number, financial status, or profitability. Two factors played decisive roles in this period. The first factor was the speedy development of township enterprises. Most of township enterprises were small and mediumsized, and thus became a key driving force for the development of Chinese SMEs. The development of township enterprises not only provided solutions for the transfer of rural surplus labor forces to nonagricultural sectors and increase of farmers' income, but also established a solid foundation for the accomplishment of the strategy of gradual reforms and development. The second factor was the rapid growth of non-public sectors of the economy, notably private-owned SMEs. As economic reforms proceeded, more and more people realized the importance of non-state-owned businesses, especially private-owned SMEs. From the very beginning of the reform and opening-up, the government acknowledged that the non-public sector of the economy would be a necessary and favorable supplement to the socialist public economy. In 2004 China amended the constitution to grant the nonpublic economy a legal status in the socialist market economy. Such a legislative move reflects China's deepened understanding of the non-public sector of the economy, which in turn gives great impetus to the development of private-owned enterprises.

\section{SOLUTIONS TO FINANCING DIFFICULTIES}

Chinese financial enterprises are primarily composed of Bank of China, ICBC, China Construction Bank and Agricultural Bank of China and dependent on China's socialist public ownership. They are businesses with deposit, loan-based, and have a distinct policy feature. However, the clients for these large-scale state-owned financial enterprises to solve the financing problems are mainly large-scale 
enterprises and institutions. An effective way of financing has not been established yet for small businesses, and the informal financing channels including private loans, guarantees and other financing ways are not well developed. Under such circumstances, it is of great importance to increase the financial support from the government and formulate effective ways of fostering small business development under the frame of macro-control.

China should increase the overall volume and proportion of credit for SMEs in the country's financial assets, especially banking credit. China boasts a large volume of financial assets, which increases very rapidly. Although the capital market has seen a fast development, the various types of bank loans would remain, within a fairly long period of time, the principal source of credit. Currently, the scarcity of capital earmarked for small and mediumsized (particularly small) enterprises is the cause of the financial predicament that faces such businesses. Increasing the volume and ratio of credit for SMEs in China's financial assets, especially banking credit capital will help create a better external environment for solving SMEs financial difficulties. Proper measures should be taken to encourage financial institutions to raise the ratio of credit capital for small and medium-sized, especially small businesses, to a proper level. The role of special SME credit-service departments at state-owned commercial banks should be fully fulfilled. A more flexible interest rate floating regime should be adopted for credit extended to SMEs, and the inappropriate management system should be reformed.

China should gradually develop specialized financial institutions to serve SMEs and reform the current financial structure and management system. Although there are many reasons for SME financing difficulties, the lack of specialized financial institutions is undoubtedly a major one. Vigorously developing small and medium-sized financial institutions and establishing and improving China's small and medium-sized financial institution system should be a major initiative for solving the problem. They should be encouraged to compete with each other to motivate them to get in touch and ultimately establish a long-term and stable cooperation with SMEs, which will lead to less information asymmetry. Developing non-state financial institutions not only serves as a supplement for the state financial institutional structure, but also solves the problem of financing difficulties faced by SMEs.

\section{CONCLUSIONS}

The reform and opening-up policy in China has resulted in a good environment for the development of small- and medium-sized enterprises (SMEs), especially the burgeoning SMEs in the private sector. SMEs have been playing an important role in China's economic reform and development and have become a growth engine in the Chinese economy. However, SMEs are still facing many financial difficulties. Thus, in the present paper, the current financial status and financial environments of SMEs in China are studied and compared with several of the western countries, and a capital-cycle-based capital utilization pattern is proposed, that is, to increase government support to control the capital investment of the enterprise, take advantage of the core competencies to ensure the full capital utilization of the enterprise, screen life cycle of the enterprise to reasonably withdraw the capital. Meanwhile, some related cases are illustrated. In the end, some concluding remarks are drawn and some suggestions are proposed.

\section{REFERENCES}

[1] Chen, J. 2006. Development of Chinese small and mediumsized enterprises. Journal of Small Business and Enterprise Development 13(2):140-147.

[2] Eyiah, A.K. \& Cook, P. 2003. Financing small and medium-scale contractors in developing countries: a Ghana case study. Construction Management and Economics 21(4):357-367.

[3] Fagan, M. \& Zhao, S. 2009. SME financing in China: the current situation, problems and possible solutions. International Journal of Entrepreneurship and Small Business 8(2):171-185.

[4] Hughes, A. 1997. Finance for SMEs: a UK perspective. Small Business Economics, 9(2): 151-168.

[5] Levratto, N. 1996. Small firms finance in France," Small Business Economics, 8(4): 279-295.

[6] Mambula, C. 2002. Perceptions of SME growth constraints in Nigeria. Journal of Small Business Management, 40(1):58-65. 